$\underset{\text { publications }}{\mathbf{C}} \mathbf{G e c . \text { Nat. Prod. 12:6 (2018) 643-647 }}$\begin{tabular}{c}
$\begin{array}{c}\text { records of natural } \\
\text { products }\end{array}$ \\
\hline
\end{tabular}

\title{
Cytotoxic Sesterterpenoids from Bornean Sponge Spongia sp.
}

\section{Chin-Soon Phan ${ }^{\oplus 1}$, Takashi Kamada ${ }^{\oplus 2}$, Toshiyuki Hamada ${ }^{\oplus 3}$ and Charles S. Vairappan ${ }^{\oplus *}$}

${ }^{1}$ Laboratory of Natural Products Chemistry, Institute for Tropical Biology and Conservation, Universiti Malaysia Sabah, 88400 Kota Kinabalu, Sabah, Malaysia

2 Laboratory of Natural Products Chemistry, Department of Materials and Life Science,

Faculty of Science and Technology, Shizuoka Institute of Science and Technology, 2200-2 Toyosawa, Fukuroi, Shizuoka 437-8555, Japan

${ }^{3}$ Graduate School of Science and Engineering, Kagoshima University, 1-21-35 Korimoto, Kagoshima 890-0065, Japan

(Received January 21, 2018; Revised April 05, 2018; Accepted April 10, 2018)

\begin{abstract}
Four scalarane sesterterpenoids, scalarolide acetate (1), scalarolide (2), 12-O-deacetyl-12-epi-19-Omethylscalarin (3) and methyl 18-hydroxy-19-norscalar-16-en-20-carboxylate (4) were isolated from the Bornean sponge Spongia sp. The distinction between $12 \alpha-\mathrm{OAc}$ and $12 \beta-\mathrm{OAc}$, and 19-olide and 20-olide in sesterterpenes were revealed as well as previously not assigned relative configuration at $18-\mathrm{OH}$ of $\mathbf{4}$ is reported herein for the first time. In addition, compounds 1-3 showed strong cytotoxic activities against adult T-cell leukemia (ATL), S1T cells. This is the first record of scalarane sesterterpenes from the Bornean sponge.
\end{abstract}

Keywords: Borneo; sponge; sesterterpenes; adult T-cell leukemia; S1T. @ 2018 ACG Publications. All rights reserved.

\section{Sample Source}

One population of Bornean sponge Spongia sp. was collected at $06^{\circ} 12^{\prime} 073^{\prime}$ N , $115^{\circ} 36^{\prime} 062^{\prime \prime}$ 'E, Mengalum Island, Sabah (Malaysia); on the 23th September 2017. The voucher specimen (BORMI0024) is kept at the BORNEENSIS (Institute for Tropical Biology and Conservation) in the Universiti Malaysia Sabah.

\section{Previous Studies}

Scalarane skeleton is a tetracyclic sesterterpenes of four fused six-membered rings, however, there are exceptions that these sesterterpenoids possessed ring E and formed pentacyclic system [1-4].

*Corresponding author: E-Mail: csv@ ums.edu.my ; Phone +60-88-320-000 ext 2397, Fax +60-88-320-291. 
It has been well characterized that both tetra- and pentacyclic system of this skeleton consisted $\mathrm{A} / \mathrm{B} / \mathrm{C} / \mathrm{D}$ ring with the conserved trans-fused junctions [5]. The structural variety of this compound's family was derived from different oxidation at C-19 and C-20 [6]. In addition, scalarane sesterterpenes are often investigated for their biological activities [1-3,7-19].

\section{Present Study}

Fresh sponge specimen ( $800 \mathrm{~g}$ wet wt) was macerated in $\mathrm{MeOH}$ at room temperature $\left(23^{\circ} \mathrm{C}\right)$. After 5 days of soaking, the resulting $\mathrm{MeOH}$ was filtered, concentrated and partitioned between two immiscible solvents EtOAc and $\mathrm{H}_{2} \mathrm{O}$. Further partition between $\mathrm{H}_{2} \mathrm{O}$ and $\mathrm{BuOH}$ was performed. A total of $1.5 \mathrm{~g}$ of crude EtOAc extract was separated via normal phase silica gel column chromatography via gradient solvent eluation of hexane-EtOAc in an increasing polarity into ten fractions. Scalarolide acetate $(\mathbf{1}, 6.2 \mathrm{mg})$ [1] was obtained through preparative TLC of fraction 7 (63.0 $\mathrm{mg}$ ) with toluene-EtOAc (8:2), while the residue was further purified to acquire 12-O-deacetyl-12-epi19-O-methylscalarin $(3,11.0 \mathrm{mg})$ [3] via preparative TLC with $\mathrm{CHCl}_{3}$-EtOAc (9:1). Fraction 4 (64.0 $\mathrm{mg}$ ) was subjected to repeated preparative TLC with toluene-EtOAc (8:2), $\mathrm{CHCl}_{3}$-EtOAc $(85: 15)$ and toluene-EtOAc (7:3) to obtained methyl 18-hydroxy-19-norscalar-16-en-20-carboxylate $(4,1.1 \mathrm{mg})$ [1]. While, scalarolide $(2,1.5 \mathrm{mg})$ [2] was afforded from faction $6(47.0 \mathrm{mg})$ via repeated preparative TLC using toluene-EtOAc (7:3) and $\mathrm{CHCl}_{3}$-EtOAc (9:1) as solvent system. Compounds $\mathbf{1}$ and $\mathbf{4}$ were first isolated from sponge Collospongia auris [1], while $\mathbf{2}$ and $\mathbf{3}$ were first reported from sponge Spongia idia and Spongia, respectively [2,3].

Compound 1; colorless oil; molecular formula of $\mathrm{C}_{27} \mathrm{H}_{40} \mathrm{O}_{4}$ from FABMS $m / z$ (rel. int.): 429 $\left([\mathrm{M}+\mathrm{H}]^{+}, 10.1 \%\right), 369(100.0 \%), 370(27.3 \%)$.

Compound 2; colorless amorphous solid; molecular formula of $\mathrm{C}_{25} \mathrm{H}_{38} \mathrm{O}_{3}$ from FABMS $\mathrm{m} / \mathrm{z}$ (rel. int.): $387\left([\mathrm{M}+\mathrm{H}]^{+}, 72.0 \%\right), 369$ (34.9\%), $307(27.7 \%), 289(15.8 \%)$.

Compound 3; white amorphous solid; molecular formula of $\mathrm{C}_{26} \mathrm{H}_{40} \mathrm{O}_{4}$ from FABMS $m / z$ (rel. int.): $417\left([\mathrm{M}+\mathrm{H}]^{+}, 51.6 \%\right), 369(26.6 \%), 307(27.0 \%), 289(14.4 \%)$.

Compound 4; colorless needles; molecular formula of $\mathrm{C}_{25} \mathrm{H}_{40} \mathrm{O}_{4}$ from FABMS $m / z$ (rel. int.): $405\left([\mathrm{M}+\mathrm{H}]^{+}, 32.2 \%\right), 387\left(\left[\mathrm{M}+\mathrm{H}-\mathrm{H}_{2} \mathrm{O}\right]^{+}, 25.5 \%\right), 355$ (23.9\%), 307 (26.9\%), $289(15.6 \%)$.

Cytotoxic assay: The RPMI-1640 medium supplemented with $10 \%$ fetal bovine serum, $100 \mathrm{U} / \mathrm{mL}$ penicillin, $100 \mu \mathrm{g} / \mathrm{mL}$ streptomycin and $2 \mathrm{mM}$ L-glutamate was used to culture ATL cell line, S1T. Cytotoxic assay was conducted by loading $1 \times 10^{4}$ cells/well in 96-well plate along with the compound which later incubated at $37^{\circ} \mathrm{C}$ with $5 \% \mathrm{CO}_{2}$ for $72 \mathrm{~h}$. Well with the absence of compound served as negative control, and etoposide as positive control. Assessment of cell viability was carried out using tetrazolium (WST-8) assay kit (Dojindo, Japan) measured at $450 \mathrm{~nm}$ with a microplate reader [20,21].

\subsection{Structure Significance and Their Cytotoxicity}

In the current study, a total of four scalarane sesterterpenoids, scalarolide acetate (1), scalarolide (2), 12-O-deacetyl-12-epi-19-O-methylscalarin (3) and methyl 18-hydroxy-19-norscalar16-en-20-carboxylate (4) have isolated and identified (Figure 1). Thorough study showed sesterterpenes isolated from nature possessed $\alpha$ or $\beta$ relative configurations for acetate or hydroxyl group at C-12, moreover the $\alpha, \beta$-unsaturated $\gamma$-lactone motif can be at 19-olide or 20-olide $[1-12,16]$. Therefore, compound $\mathbf{1}$ served as model compound for comparison of latter configurations in the scalarane sesterterpenes. 
The vicinal proton-proton coupling constants were significantly differed between $12 \beta$-OAc in 1 and $12 \alpha-O A c$ sesterterpenes. The acetoxy-bearing methine $\mathrm{H}-12 \alpha\left(\delta_{\mathrm{H}} 4.92, \mathrm{dd}, J=10.9,4.8 \mathrm{~Hz}\right)$ in 1 was not consistent to those of acetoxy-bearing methine $\mathrm{H}-12 \beta$ in 12-epi-acetylscalarolide $\left(\delta_{\mathrm{H}} 5.54\right.$, $\mathrm{dd}, J=2.9,2.7 \mathrm{~Hz}), 16$-acetylfuroscalarol $\left(\delta_{\mathrm{H}} 5.41, \mathrm{dd}, J=2.8,2.8 \mathrm{~Hz}\right)$, hyatelone A $\left(\delta_{\mathrm{H}} 5.31, \mathrm{dd}, J=\right.$ $3.5,2.2 \mathrm{~Hz}), 20-O$-acetylhyatolide $\mathrm{C}\left(\delta_{\mathrm{H}} 5.49, \mathrm{dd}, J=2.9,2.3 \mathrm{~Hz}\right)$ and $12 \alpha$-acetoxy-13 $\beta, 18 \beta-$ cyclobutane-20,24-dimethyl-24-oxoscalar-16-en-25 $\alpha$-ol $\left(\delta_{\mathrm{H}} 5.66, \mathrm{t}, J=3.0 \mathrm{~Hz}\right)[4,10,11]$. Other $12 \beta-$ OAc sesterterpenes such as $12 \beta$-acetoxy, $16 \beta$-methoxy, $20 \alpha$-hydroxy-17-scalaren-19,20-olide $\left(\delta_{\mathrm{H}} 4.88\right.$, $\mathrm{dd}, J=10.8,3.6 \mathrm{~Hz})$ and 12 -epi-scalaradial $\left(\delta_{\mathrm{H}} 4.80, \mathrm{dd}, J=10.0,4.0 \mathrm{~Hz}\right)$ were found matching to those of $\mathbf{1}[12,22]$. This finding suggested that $12 \beta-\mathrm{OAc}$ bearing methine has a smaller ${ }^{3} J_{\mathrm{HH}}$ compared to those of $12 \alpha-\mathrm{OAc}$ bearing methine. This deduction was also consistent in $12 \beta-\mathrm{OH}$ and $12 \alpha-\mathrm{OH}$ bearing methine of sesterterpenes. The chemical shifts for $\alpha, \beta$-unsaturated $\gamma$-lactone unit of 20 -olide in $1\left(\delta_{\mathrm{C}} 171.0,161.3,134.4\right.$ and $70.1 ; \delta_{\mathrm{H}} 4.55$ and 4.47$)$ was significantly differed to those of 19 -olide in isomer $1\left(\delta_{\mathrm{C}} 174.1,167.3,125.5\right.$ and $68.1 ; \delta_{\mathrm{H}} 4.70$ and 4.42$)[23]$.
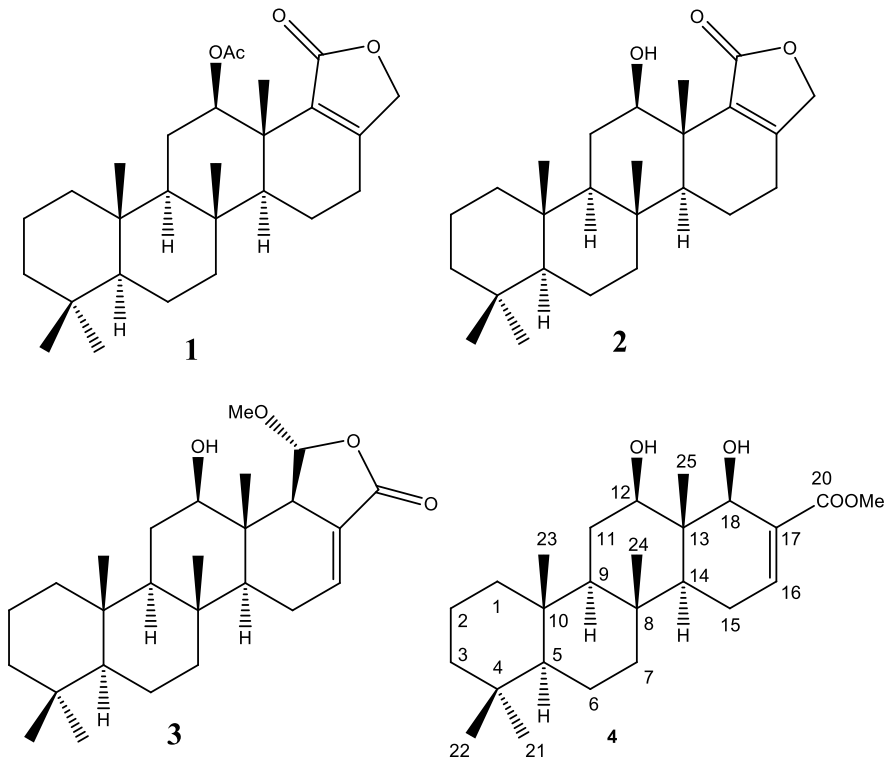

Figure 1. Structures of 1-4.

The relative configuration of 18-OH of $\mathbf{4}$ was not assigned when first reported by Bergquist et al. (1990) [1]. In this regard, $\beta$ relative configuration was assigned on $18-\mathrm{OH}$ based on NOESY cross peaks of $\mathrm{H}-12 / \mathrm{H}-18 ; \mathrm{H}-12 / \mathrm{H}-14 ; \mathrm{H}-14 / \mathrm{H} 18 ; 12-\mathrm{OH} / 18-\mathrm{OH}$; and $18-\mathrm{OH} / \mathrm{H}_{3}-25$ (Figure 2). The aggressive malignancy on mature activated T-cells due to infection of human T-cell lymphotropic virus type I was characterized as adult T-cell leukemia (ATL) which exclusively found in the areas of South American, Japan, Northern Iran, the Caribbean Basin, Southern India, West-Central Africa and some isolated region in tropics [24]. Compounds 1-3 displayed potent cytotoxicity towards ATL, S1T cell lines with the $\mathrm{IC}_{50} 5.16,3.93$ and $2.31 \mathrm{ug} / \mathrm{mL}$, respectively. Unfortunately, compound 4 was not evaluated for its biological activities due to its limitation availability. Nevertheless, to the best of our knowledge, this is the first report of sponge-derived secondary metabolites evaluated on ATL cell lines. Previous investigation showed these scalarane sesterterpenes have tested for their antimicrobial [1], and antifeedant activities [2]. Besides that, compound $\mathbf{3}$ was reported to inhibit the interaction between farnesoid X-activated receptor and coactivator peptide (SRC-1) [3]. In addition, plateletaggregation inhibitory [15], anti-inflammatory [16], anti-fouling [17], ichthyotoxic [18], and cytotoxic properties [19], were reported from this compound's family. Owing to their intrigued biological activities, these compounds are promising to further investigate for the mechanism of their cytotoxicity towards ATL that involved pro-apoptotic proteins. 


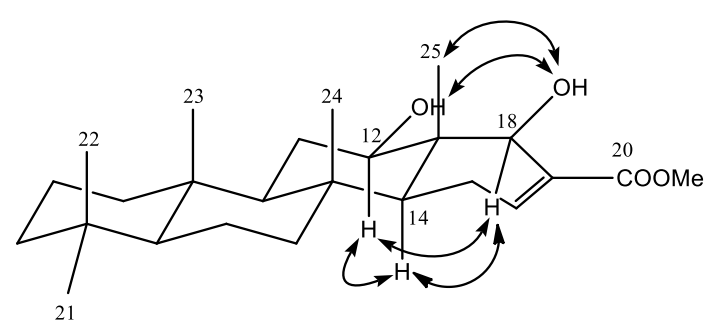

Figure 2. The key NOE correlations of 4.

\section{Acknowledgments}

This work was supported financially by the Sabah Biodiversity Centre [Grant No. GL0070]. The authors would also like to acknowledge Prof. Dr. Naomichi Arima (Kagoshima University) for providing ATL cancer cell line, S1T.

\section{Supporting Information}

Supporting Information accompanies this paper on http://www.acgpubs.org/RNP

\section{ORCID}

Chin-Soon Phan: 0000-0002-6500-696X

Takashi Kamada: 0000-0002-2886-4623

Toshiyuki Hamada: 0000-0002-7631-7974

Charles S. Vairappan: 0000-0001-7453-1718

\section{References}

[1] P.R. Bergquist, R.C. Cambie and M.R. Kernan (1990). Scalarane sesterterpenes from Collospongia auris, a new thorectid sponge, Biochem. Syst. Ecol. 18, 349-357.

[2] R.P. Walker, J.E. Thompson and D.J. Faulkner (1980). Sesterterpenes from Spongia idia, J. Org. Chem. 45, 4976-4979.

[3] S.J. Nam, H. Ko, M.K. Ju, H. Hwang, J. Chin, J. Ham, B. Lee, J. Lee, D.H. Won, H. Choi, J. Ko, K. Shin, T. Oh, S. Kim, J.R. Rho and H. Kang (2007). Scalarane sesterterpenes from a marine sponge of the genus Spongia and their FXR antagonistic activity, J. Nat. Prod. 70, 1691-1695.

[4] C.J. Hernández-Guerrero, E. Zubía, M.J. Ortega and J.L. Carbollo (2006). Sesterterpene metabolites from the sponge Hyatella intestinalis, Tetrahedron. 62, 5392-5400.

[5] H.J. Li, T. Amagata, K. Tenney and P. Crews (2007). Additional scalarane sesterterpenes from the sponge Phyllospongia papyracea. J. Nat. Prod. 70, 802-807.

[6] V. Kulciţki, N. Ungur, M. Gavagnin, F. Castelluccio and G. Cimino (2007). Ring B functionalization of scalarane sesterterpenes by radical relay hydrogenation. Tetrahedron. 63, 7617-7623.

[7] K.P. Lutta, B. Christine, A.A. Teresa and W.W. Cornelius (2008). Antimicrobial marine natural products from the sponge, Axinella infundibuliformis, Rec. Nat. Prod. 2, 116-127.

[8] N. Aktas, Y. Genc, B. Gozcelioglu, B. Konuklugil and U.S. Harput (2013). Radical scavenging effect of different marine sponges from Mediterranean Coasts, Rec. Nat. Prod. 7, 96-104.

[9] F.C. Özkaya, E. Bedir and E.E. Hameş (2015). A new siderophore from sponge associated Pseudomonas fluorescens 4.9.3, Rec. Nat. Prod. 9, 509-517.

[10] A. Rueda, E. Zubía, M.J. Ortega, J.L. Carbollo and J. Salvá (1997). New cytotoxic metabolites from the sponge Cacospongia scalaris, J. Org. Chem. 62, 1481-1485.

[11] H.J. Li, T. Amagata, K. Tenney and P. Crews (2007). Additional scalarane sesterterpenes from the sponge Phyllospongia papyracea, J. Nat. Prod. 70, 802-807. 
[12] S.S. Elhady, A.M. Al-abd, A.M. El-Halawany, A.M. Alahdal, H.A. Hassanean and S.A. Ahmed (2016). Antiproliferative scalarane-based metabolites from the Red Sea sponge Hyrtios erectus, Mar. Drugs. 14, 130-143.

[13] S. Tang, R. Xu, W. Lin and H. Duan (2012). Jaspiferin A and B: two new secondary metabolites from the South China Sea sponge Jaspis stellifera, Rec. Nat. Prod. 6, 398-401.

[14] I.E. Orhan, B. Ozcelik, B. Konuklugil, A. Putz, U.G. Kaban and P. Proksch (2012). Bioactivity screening of the selected Turkish marine sponges and three compounds from Agelas oroides, Rec. Nat. Prod. 6, 356-367.

[15] M. Nakagawa, Y. Hamamoto, M. Ishihama, S. Hamasaki and M. Endo (1987). Pharmacologically active homosesterterpenes from Palauan sponges, Tetrahedron Lett. 28, 431-434.

[16] A. Fontana, E. Mollo, J. Ortea, M. Gavagnin and G. Cimino (2000). Scalarane and homoscalarane compounds from the nudibranchs Glossodoris sedna and Glossodoris dalli: Chemical and biological properties, J. Nat. Prod. 63, 527-530.

[17] Y. Sera, K. Adachi and Y. Shizuri (1999). A new epidioxy sterol as an antifouling substance from a Palauan marine sponge, Lendenfeldia chondrodes. J. Nat. Prod. 62, 152-154.

[18] J.C. Braekman, D. Daloze, M. Kaisin and B. Moussiaux (1985). Ichthyotoxic sesterterpenoids from the Neo Guinean sponge Carteriospongia foliascens, Tetrahedron 41, 4603-4614.

[19] J. Song, W. Jeong, N. Wang, H.S. Lee, C.J. Sim, K.B. Oh and J. Shin (2008). Scalarane sesterterpenes from the sponge Smenospongia sp., J. Nat. Prod. 71, 1866-1871.

[20] C.S. Phan, T. Kamada, K. Kobayashi, T. Hamada and C.S. Vairappan (2018). 15-Deoxy-isoxeniolide-A, new diterpenoid from a Bornean soft coral, Xenia sp., Nat. Prod. Res. 32, 202-207.

[21] C.S. Phan, T. Kamada, T. Ishii, T. Hamada and C.S. Vairappan (2017). 12-Epi-9-deacetoxyxenicin, new cytotoxic diterpenoid from a Bornean soft coral, Xenia sp. Nat. Prod. Res. 1-6. doi: $10.1080 / 14786419.2017 .1410812$

[22] G. Cimino, S. De Stefano and A. Di Luccia (1979). Further sesterterpenes from the sponge Spongia nitens: 12-epi-scalaradial and 12,18-diepi-scalaradial, Experientia. 35, 1277-1278.

[23] Z.L. Wang, Z.G. Zhang, H.C. Li and W.P. Deng (2011). Concise stereoselective synthesis of marine sesterterpene, 16-deacetoxy-12-epi-scalarafuran acetate and its 14-epimer via intramolecular DielsAlder addition, Tetrahedron 67, 6939-6943.

[24] F.A. Proietti, A.B. Carneiro-Proietti, B.C. Catalan-Soares and E.L. Murphy (2005). Global epidemiology of HTLV-I infection and associated diseases, Oncogene 24, 6058-6068.

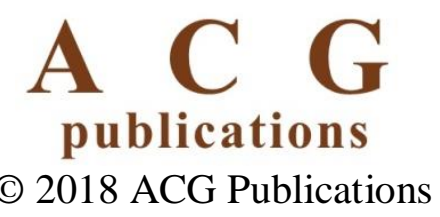

